\title{
Antecedents and outcomes of supplier innovativeness in international customer-supplier relationships: The role of knowledge distance
}

DOI:

10.1007/s11575-016-0291-x

\section{Document Version}

Accepted author manuscript

Link to publication record in Manchester Research Explorer

Citation for published version (APA):

Jean, R-J., Sinkovics, R. R., \& Kim, D. (2017). Antecedents and outcomes of supplier innovativeness in international customer-supplier relationships: The role of knowledge distance. Management International Review, 57(1), 121-151. https://doi.org/10.1007/s11575-016-0291-x

\section{Published in:}

Management International Review

\section{Citing this paper}

Please note that where the full-text provided on Manchester Research Explorer is the Author Accepted Manuscript or Proof version this may differ from the final Published version. If citing, it is advised that you check and use the publisher's definitive version.

\section{General rights}

Copyright and moral rights for the publications made accessible in the Research Explorer are retained by the authors and/or other copyright owners and it is a condition of accessing publications that users recognise and abide by the legal requirements associated with these rights.

\section{Takedown policy}

If you believe that this document breaches copyright please refer to the University of Manchester's Takedown Procedures [http://man.ac.uk/04Y6Bo] or contact uml.scholarlycommunications@manchester.ac.uk providing relevant details, so we can investigate your claim.

\section{OPEN ACCESS}




\title{
Antecedents and Outcomes of Supplier Innovativeness in International Customer-Supplier Relationships: The Role of Knowledge Distance
}

\author{
Ruey-Jer 'Bryan' Jean • Rudolf R. Sinkovics • Daekwan Kim
}

\section{This is an Author's Original Manuscript (AAM) of an article published by Springer in Management International Review. Please cite the published article:}

Jean, Ruey-Jer "Bryan", Rudolf R. Sinkovics, and Daekwan Kim (2017), "Antecedents and outcomes of supplier innovativeness in international customer-supplier relationships: The role of knowledge distance," Management International Review, 57 (1), 121-151. (DOI:

10.1007/s11575-016-0291-x).

http://dx.doi.org/10.1007/s11575-016-0291-x

\section{Abstract}

- The increasing competitive pressures and speed of $R \& D$ and product innovation is prompting many multinational enterprise (MNE) customers to outsource their core activities to suppliers. Despite organizational challenges due to cultural and physical separation from their partners, these are now charged with supplier-driven innovation.

- This study looks at key drivers of supplier innovativeness, examines the role of crossnational differences in shaping supplier innovativeness and examines the impact of this dimension on relationship performance in international customer-supplier relationships.

- Our findings from a large-scale survey of Taiwanese electronics suppliers provide evidence of the contribution of antecedents such as customer orientation, customer control and technological uncertainty to the enhancement of supplier innovativeness. Innovativeness contributes to increased customer dependence and improves relationship performance. Differences in knowledge bases stemming from different institutions are also tested in this study; we find that knowledge distance may be detrimental to the innovativenessperformance link in international exchange relationships. 


\section{Keywords}

- Supplier innovativeness; dependence; customer orientation; knowledge distance; relationship performance

\section{Authors}

Ruey-Jer 'Bryan' Jean

Associate Professor of International Business

National Chengchi University

64, Sec.2 Zhi-Nan Road, Taipei, 11605, Taiwan

bryan@nccu.edu.tw

Rudolf R. Sinkovics ( $\square)$

Professor of International Business

The University of Manchester, Alliance Manchester Business School

Booth Street West, Manchester M15 6PB, UK.

and Lappeenranta University of Technology, Skinnarilankatu 34, PL 20, FI-53851

Lappeenranta, Finland

Rudolf.Sinkovics@manchester.ac.uk,www.manchester.ac.uk/research/rudolf.sinkovics

Daekwan Kim

Associate Professor of International Marketing

Florida State University

Department of MarketingCollege of Business

Tallahassee, FL 32306-1110, USA

dkim@fsu.edu

\section{Manuscript information}

- Manuscript Submitted: July 30, 2014

- Revision: September 26, 2015, May 02, 2016

- Accepted: May 05, 2016 


\title{
Antecedents and Outcomes of Supplier Innovativeness in International Customer-Supplier Relationships: The Role of Knowledge Distance
}

\begin{abstract}
The increasing competitive pressures and speed of $R \& D$ and product innovation is prompting many multinational enterprise (MNE) customers to outsource their core activities to suppliers. Despite organizational challenges due to cultural and physical separation from their partners, these are now charged with supplier-driven innovation. This study looks at key drivers of supplier innovativeness, examines the role of cross-national differences in shaping supplier innovativeness and examines the impact of this dimension on relationship performance in international customer-supplier relationships. Our findings from a large-scale survey of Taiwanese electronics suppliers provide evidence of the contribution of antecedents such as customer orientation, customer control and technological uncertainty to the enhancement of supplier innovativeness. Innovativeness contributes to increased customer dependence and improves relationship performance. Differences in knowledge bases stemming from different institutions are also tested in this study; we find that knowledge distance may be detrimental to the innovativeness-performance link in international exchange relationships.
\end{abstract}

\section{KEYWORDS}

Supplier innovativeness; dependence; customer orientation; knowledge distance; relationship performance 


\section{Antecedents and Outcomes of Supplier Innovativeness in International Customer-Supplier Relationships: The Role of Knowledge Distance}

\section{Introduction}

Innovation outsourcing has become a megatrend for many firms in various industries (Quinn 2000). Globalization is forcing companies, and particularly multinational enterprises (MNEs), to internationalize their knowledge-intensive corporate functions, including R\&D, and simultaneously open up their innovation processes to collaborative external partnerships with suppliers, customers, and contract manufacturers. For example, Hewlett-Packard has required the assistance of supply firms with the development of new products ranging from printers to IT services, and has shifted its R\&D centers to emerging markets like China. This trend towards innovation outsourcing is driving suppliers in emerging or developing markets to be more actively involved with MNE customers in the global innovation network. However, this shift towards supplier-driven innovation also faces many challenges. This is particularly true for global markets, where customer-supplier relationships span geographical, political, and cultural borders. Institutional distance results in knowledge gaps between exchange parties and affects knowledge acquisition and integration in international exchange relationships, which in turn may influence innovation generation and its performance outcomes. In addition, supplying firms from emerging markets usually lack sufficient absorptive capacity, which hampers their development toward cutting-edge and radical innovation.

While intensified globalization has resulted in firms relying heavily on external innovative suppliers, relatively little research has explored innovation activities in the international supply chain (customer-supplier) context (Roy et al. 2004). Roy et al. (2004) note that there is a "dearth of research" on innovation generation in buyer-seller relationships. While previous studies identify some key drivers of organizational innovation, such as organizational culture, structure and environments, some relationships are still empirically unsubstantiated. Although prior work examines institutional aspects of knowledge differences between home and host countries and their effects on firms' foreign direct investments (Guler and Guillén 2010) or subsidiary innovation (Hilmola et al. 2005; Kumaraswamy et al. 2012), no empirical study in the literature has explored the impact of knowledge differences between exchange parties on 
innovation outcomes in the context of cross-border exchange relationships. The difference in institutional environments in general, and knowledge distance in particular, may play a crucial role in shaping emerging market firms' strategies and capabilities in dealing with international partners (Sultan 2010). For example, a poorly developed institutional support infrastructure with a lack of strong intellectual property protection (IPR) in China provides a weak base for local firms wishing to nurture knowledge resources gained from international alliance partners (Li et al. 2012). In addition, findings relating to the performance implications of firm innovativeness vary substantially across studies. For instance, while the predominant view is that innovativeness is positively related to performance, some research has reported non-significant or even negative effects for this association (Rubera and Kirca 2011). Finally, most prior work focuses on examining firms' innovative behaviors in the context of developed markets and original equipment manufacturer (OEM) buyers, while theoretical discussions and empirical tests related to innovation by supplying firms in the context of developing markets have been limited ( $\mathrm{Li}$ et al. 2010).

The primary objective of this study is to overcome these shortcomings by developing and testing a model that examines antecedents and performance outcomes of supplier innovativeness in international customer-supplier relationships in an emerging market. Specifically, the study addresses the following research questions: (1) What are the key drivers of supplier innovativeness in emerging market customer-supplier relationships? Specifically, what are the organizational (supplier customer orientation), interorganizational (customer control), and environmental (technological dynamism) factors impacting on suppliers' innovativeness in international exchange relationships? (2) How and to what extent does emerging market supplier innovativeness affect customer dependence and relationship performance in international customer-supplier relationships? (3) How and to what extent does knowledge distance shape the performance outcomes of supplier innovativeness in an emerging market?

This study contributes to existing knowledge in three ways. First, while prior studies focus on the innovation activities of MNEs and their subsidiaries in the global market, this study investigates the innovation generation by emerging market suppliers in international customersupplier relationships. In combining theoretically grounded antecedents, mediation and moderating relationships with performance outcomes (see e.g. Bello et al. 2003; Sinkovics et al. 
2010), this study responds to the call for more empirical research on innovation in the context of international supply chains (Roy et al. 2004).

Second, drawing on institutional aspects of the cross-national distance (Berry et al. 2010) and national innovation system literature, this study examines the impact of knowledge distance (i.e. the difference in knowledge stocks between exchange parties' countries of origin) on firms' innovation outcomes. According to this stream of research, innovative capabilities depend on the density and quality of relationships among firms and support institutions. Prior research shows that national culture (Hofstede 1984) plays a critically important role in shaping firms' innovation. However, empirical evidence, drawing mostly on Hofstede's national culture dimension, provides contradictory and mixed results on the link between cross-cultural distance and innovation (Tellis et al. 2009a; Tellis et al. 2003; Tellis et al. 2009b). For example, Nakata and Sivakumar (1996) propose that masculinity has different effects on product innovation in different innovation processes. Further, the empirical study by Tellis et al. (2009a) reveals no significant relationship between the masculinity dimension and firm innovation. To resolve the paradox and contribute to this stream of research, we follow recent institutional theorizing in the field of international business (Berry et al. 2010) and investigate the associations between the differences in the configuration of institutions that foster the outcomes of innovativeness. We concur with Sinkovics et al. (2010) and are interested in a deeper understanding of the sources of potential similarities/differences. We thus argue that knowledge distance may be a distance variable that is particularly relevant to examining firm innovation behavior in cross-border exchange relationships, particularly in emerging markets. A weak and insufficient institutional environment exhibiting a lack of sufficient IPR protection may incur high coordination and transaction costs in international exchange relationships and thus inhibit knowledge transfer and exchange. While prior work applies this notion to innovation generation in the MNE-subsidiary context (Hilmola et al. 2005; Luo et al. 2011), no significant attention has been paid to the influence of institution-based knowledge differences between exchange partners from different countries on innovation generation within global supply chain relationships. The central contribution of this study is to address this gap in the literature by extending the role of institutional environment on innovation from the MNE-subsidiary context to global supply chains. This is consistent with the emerging stream of institutional theory in international business research, which highlights the role of institutional environments in shaping strategies, 
resources and capability development for foreign entrants or local firms in emerging markets (Luo et al. 2011; Meyer et al. 2011).

The empirical setting of this paper includes cross-border customer-supplier relationships between Taiwanese contract manufacturers (suppliers) and their international OEM customers in the electronics industry. International OEM customer-supplier relationships in the Taiwanese electronics industry are an excellent setting for this study for the following reasons: (a) Taiwanese suppliers are more dependent on international OEM customers, and exhibit significant power asymmetry in exchange relationships (Chang and Gotcher 2007; Jean et al. 2010; Kang et al. 2009). (b) Many Taiwanese suppliers play active roles in product innovation for their international OEM customers, are "connective nodes" in supply networks (Andersen and Christensen 2005), and have transitioned from the role of OEM to that of original design manufacturers (ODMs). New product development is a critical and particularly challenging task for these types of firms because they operate with limited resources and organizational capabilities. With the dynamism of global competition, Taiwanese suppliers have been striving to enhance their innovative capabilities by providing better products and services to their international OEM customers, which, in turn, can increase their margins and bargaining power against global buyers. Hence, this unique context can provide empirical evidence on how emerging country firms develop innovative capabilities in relationships with their international customers.

This article is organized as follows. The following section proposes a conceptual model that delineates the relationships among key constructs. A literature review of resource dependence theory (RDT), the resource-based view (RBV) and institutional aspects of knowledge distance provides support for the relationships between each of the dimensions included. This paper offers predictions regarding the antecedents and consequences of supplier innovativeness, tests these hypotheses empirically, and presents the results. The paper concludes with a discussion of the findings and directions for future research.

\section{Conceptual framework and hypotheses}

This study explores supplier innovativeness as the focal concept in this study. It refers to the extent to which suppliers are inclined to engage in innovative behavior such as adopting new 
ideas or new technology (Deshpandé et al. 2004; Hurley and Hult 1998). However, this study differentiates innovativeness from innovation since innovation is typically an outcome-oriented measure such as "new product innovation", while innovativeness captures the firm-level orientation toward innovation (Rubera and Kirca 2011). The focus of our study is on how suppliers can develop their innovative capabilities within global value chains.

Innovative capability plays a crucial role in enhancing emerging market firms' competitiveness in the global market. With the increasing global-level competition, the profits of contract manufacturing suppliers in emerging markets have dropped significantly in recent years. The literature on global value chains and firm upgrading also highlights the importance of developing firms' innovation capabilities (Kumaraswamy et al. 2012). In line with this new trend, most supplying firms in Taiwan, for instance, have taken over high-value-added activities like product concept design and design of manufacturing from their global customers (Hilmola et al. 2005).

Previous studies examine a number of factors affecting firm-level innovation orientation and innovativeness including firm characteristics and the environment in which the firm is doing business. Specifically, firm characteristics such as structure, size, and culture (e.g. Frambach and Schillewaert 2002; Stock and Zacharias 2010) and environmental characteristics such as uncertainty and competition intensity are also important drivers of a firm's innovativeness (Frambach and Schillewaert 2002). However, there are two important areas that deserve further research attention. First, prior research explored firm innovativeness mostly with intraorganization views (Rubera and Kirca 2011) and relatively few studies examined firm innovativeness in the interorganizational context (Azadegan and Dooley 2010). Second, the literature has remained muted on how firm innovativeness is shaped up differently across countries depending on the business and environments.

Cultural differences may not only account for variations in firms' innovation but also influence the innovation-performance relationship because national cultural differences affect firms' organizational orientation toward innovation (Tellis et al. 2009b). However, empirical evidence on the effect of cultural differences on the innovation-performance link shows mixed results. For example, Rosenbusch et al. (2011) show that firms reap more benefits from innovation in a highly individualistic society. Contrastingly, in their meta-analysis on innovation, 
Rubera and Kirca (2011) find no significant moderating effects of national culture on the innovation-performance link.

To shed light on these voids in this stream of research, the conceptual framework of this study draws on three theories including the RDT (Pfeffer and Salancik 1978), the RBV (Barney 1991), and the institutional perspective of cross-national distance research related to international business (Berry et al. 2010) as shown in Figure 1. The conceptual framework focuses on a firm's internal and external characteristics as drivers of its innovativeness, and the outcomes of innovativeness and their moderators. The RBV identifies a firm's internal characteristics as a potential resource (Barney 1991) while the RDT and institutional perspective recognize a firm's external factors that explain its organizational culture and differing outcomes given similar resources (Berry et al. 2010; Pfeffer and Salancik 1978).

The RBV argues that a firm's valuable, rare, socially complex, and inimitable resources generate a competitive advantage. According to the RBV, innovativeness is a valuable resource that enhances a firm's competitive advantage (Menguc and Auh 2006). On the other hand, RDT stresses that the environment and other external forces can determine how firms organize themselves to compete in the marketplace (Pfeffer and Salancik 1978). According to RDT, firms attempt to manage uncertainty and mitigate the effects of external forces in order to enhance their performance. At the same time, firms are constrained by and depend on other organizations that control resources that are critical for them according to the view. Following the logic of RDT, Li and Atuahene-Gima (2001) maintain that the success of a firm's innovation strategies depends on perceived environmental conditions and relationship-based strategies. That is, firms try to enhance their innovative capability to respond to environmental changes and cope with dynamic relationship structures.

The RBV and RDT are adopted independently to explain the findings of prior research regarding firms' innovation behaviors in the literature (Li and Atuahene-Gima 2001; Renko et al. 2009). While the RBV focuses on an internal perspective, and discusses how firms specify valuable resources so as to create competitive advantage (Barney 1991), RDT emphasizes and takes on an external perspective and discusses how organizations obtain external resources to reduce resource dependence and increase power (Li and Atuahene-Gima 2001; Pfeffer and Salancik 1978). However, these two theoretical perspectives share resources as critical factors of 
firm success. Because of the complementarities in these resource perspectives, an integrative view of these theories can offer new insights into how suppliers develop innovative capabilities in managing international exchange relationships and accommodate external environmental uncertainties (Hillman et al. 2009).

Combining those two theoretical perspectives, this study examines suppliers' internal and external sources of resources as the antecedents of supplier innovativeness. Specifically, we explore customer orientation, a firm's internal characteristic, and customer's control and technological uncertainty, a firm's external characteristics, as the explaining variables of supplier innovativeness. The literature has identified a set of antecedents of innovation. Most work focused on organizational (Jansen et al. 2006), interoganizational (Cui and O'Connor 2012) and environmental variables as antecedents of firms' innovation (Koberg et al. 2003). Particularly, customer orientation has been identified as a key organizational variable of innovation (Kim and Atuahene-Gima 2010). In this study, we are arguing that a firm's customer orientation influences its innovativeness as a part of its efforts to meet the requirements of global buyers. In addition, interorganziatioal governance mechanisms such as output and process control have been suggested in the literature as a critical interorganizational variable that may shape a firm's innovation generation (Carson 2007). In addition, the literature also suggests that technological uncertainty may create opportunities, nurturing innovation generation (Sheng et al. 2011). Accordingly, customer control and technological uncertainty are explored in this study as interorganizational and environmental variables that shape up suppliers' culture toward innovation generation.

In addition, the selection of these factors follows the logic of the RBV and RDT. According to the RBV, customer orientation is a critical organizational culture that can facilitate firm innovation (Menguc and Auh 2006). Furthermore, following the perspective of RDT, suppliers will try to be more innovative so as to respond to power imbalances that originate from customers' control behaviors in international customer-supplier relationships. He Technological uncertainty can also drive suppliers to be more innovative, as firms must reduce environmental uncertainty and dependence (Li and Atuahene-Gima 2001).

In terms of performance outcomes of supplier innovativeness, both the RBV and RDT offer a plausible explanation on the impact of supplier innovativeness on firm performance. 
From the RBV's point of view, supplier innovativeness is a rare and valuable firm resource that drives supplier relationship performance (Teece et al. 1997) while RDT advocates that supplier innovativeness is a valuable resource and dependence-balancing strategy that enhances partner dependence (Li and Atuahene-Gima 2001; Pfeffer and Salancik 1978). If a resource is important for a supplier's success, which means there is no practical alternative to it, that resource ultimately serves as a basis for organizational power and increases customer dependence (Medcof 2001). This is particularly relevant for emerging market firms, which usually lack bargaining power in dealing with international customers in global value chains (Morrison et al. 2008; Pietrobelli and Rabellotti 2011). Furthermore, this perspective bridges the RBV and RDT arguments on the importance of firm resources by investigating the direct and indirect relationships between supplier innovativeness and performance..

To further our understanding of how cross-national distance shapes innovation in crossborder inter-organizational relationships, the model in this study draws on the institutional approach of cross-national distance (Berry et al. 2010; Guler and Guillén 2010) and investigates the moderating effect of knowledge distance on the outcome of supplier innovativeness. Knowledge distance is characterized by the knowledge gaps between the countries of origin of the supplier and its international customer. The national innovation system literature suggests that countries differ in terms of the inputs allocated to the creation of knowledge, technology and innovation, the quality of the institutions that help transform those inputs, and the resulting level of performance (Furman et al. 2002). In sum, the difference in knowledge distance between suppliers and their international customers can shape the effect of supplier innovativeness on firm relationship performance in the context of international customer-supplier relationships. Only when a supplier's innovative capabilities align with its institutional difference in terms of its knowledge distance from its customer, can those capabilities help the supplier to deliver a better performance.

Differences in national levels of innovation are likely to influence firm innovation activities for the following reasons. First, firms are embedded in their institutional environments, which determine their ability to produce knowledge (Cantwell and Janne 1999). The emerging institutional theory in international business argues that formal and informal institutions, known as the "rules of the game", can be expected to shape firm strategy and performance (Peng et al. 2008). This is particularly the case in emerging markets where institutions differ significantly 
from those of developed countries and have experienced significant transitions. Prior research has developed the concept of institutional distance and discussed its influence on firms' strategic behaviors. Institutional distance refers to the differences between institutional settings, which may surface in terms of differences in formalized laws, regulations, and monitoring/enforcement approaches, or differences in the more informal norms, values, and beliefs, between settings (Xu and Shenkar 2002). Second, the differences in the configurations of institutions that foster the development of knowledge in different countries may influence knowledge integration and generation for firms in relationships with cross-national partners, which in turn may influence the outcomes of firm innovation. While prior work has examined the impact of knowledge distance on firms' foreign investments strategies (Guler and Guillén 2010), its influence on firm innovation in international exchange relationships has not been addressed in the literature. Accordingly, we examine the moderating effect of knowledge distance between the supplier and its international customer on the supplier innovativeness-performance link.

\section{Insert Figure 1 here}

\subsection{The influence of the supplier's customer orientation on the supplier's innovativeness}

According to Atuahene-Gima (2005), the supplier's customer orientation refers to their commitment to generate information about current and future customers, and to disseminate and use this information within the firm. Earlier literature on market orientation views customer orientation as a critical element of organizational culture and a strategic orientation supporting firm innovation (e.g., Gatignon and Xuereb 1997; Han et al. 1998). The RBV argues that firm resources can complement each other and contribute to the development of dynamic capabilities (Teece et al. 1997). Empirical research supports the idea that customer orientation is an organizational resource that can complement innovativeness in driving firm competitiveness (Menguc and Auh 2006). For a supplier, customer orientation is a critical organizational culture element and capability that can stimulate innovative capability in the cross-border relationship. A customer-oriented supplier exhibits a more positive attitude towards its international customer and keeps track of the customer's current and future preferences. This process can help the 
supplying firm to generate innovative ideas. For supplying firms with limited resources and capabilities, it is essential that they understand and analyze the explicit and latent needs of their international customers so as to develop better customer knowledge for product innovation (Johnsen et al. 2006; Joshi and Sharma 2004). This is consistent with RDT, which treats customer orientation as an internal organizational environment that can cultivate supplier innovativeness in response to environmental changes.

However, prior research indicates the potential negative effects of listening too closely to one's customers (Blocker et al. 2010; Narver et al. 2004). Those companies that only respond to customers' needs may lose out in terms of new insights and innovativeness. Hence, it is critical to develop proactive customer orientation instead of responsive customer orientation in order stay ahead of the competition and be innovative. This is particularly important for emerging market firms because firms typically lack sufficient internal $R \& D$ to create new knowledge and have to rely on external channel members to access novel knowledge so as to be innovative. A customer-oriented supplier will proactively collect information about their international customers and transform external market information and technological knowledge into new organizational knowledge and, eventually, enhanced innovative capability (e.g. Zhou et al. 2005). Hence,

H1: In international customer-supplier relationships, a local supplier's customer orientation is positively related to the local supplier's innovativeness.

\subsection{The influence of international customer control on supplier innovativeness}

This study focuses on an international customer's control mechanism as the driving force behind supplier innovativeness. Control is the extent to which the customer has authority or influence over decisions made by the supplier (Heide et al. 2007). Control is thus unilateral governance and is related to power. The extant literature discusses different types of control mechanisms, such as output, process and social control. Prior studies attempt to explore the effects of different interorganizational governance mechanisms on international exchange relationships (e.g. Wang et al. 2008). However, empirical evidence on the link between interorganizational governance and innovation is limited and the existing findings show mixed results. For example, Wang et al. (2008) find no significant relationship between control and creativity. However, in a study on new product innovation outsourcing, Carson (2007) finds that 
control is negatively related to suppliers' task performance when the outsourced task is of a more creative nature. He argues that control limits the ability to perform creative tasks because control leads to greater formalization in the relational governance process.

In examining the link between control and innovation, this study draws on RDT and argues that customer control enhances power over suppliers through critical resources. An international customer's use of control can establish standards for quality, delivery, and operational aspects for suppliers in the new product development process. According to RDT, organizations depend on the resources traded in exchange relationships for their survival, and these resources will guarantee working exchange relationships with other organizations. Hence, this study argues that an international customer's unilateral control over the supplier creates coercive power and provides valuable resources that drive the supplier to take strategic actions to accommodate the international customer and reduce the power it has over them. Control by an international customer also gives the supplier specific guidance and leadership in the collaboration process, which may help the supplier to generate more innovative ideas. This is particularly important in the international context because geographical and cultural distance reduces interaction opportunities and increases coordination costs. Following the logic of RDT, compliance becomes more likely when few alternative resources exist in the exchange relationship. Empirical evidence also shows that a customer's assistance is conducive to the supplier showing more innovative behavior (Henke and Zhang 2010). A high level of international customer control signals greater customer assistance, which enables suppliers to engage in more innovative investments.

Customer relationships play an important role, particularly for emerging market firms, in improving their innovative abilities. Research shows that repeated interactions between exchange partners can facilitate the sharing of tacit knowledge and learning, which result in new ideas and processes. In the context of the Indian automotive industry, Kumaraswamy et al. (2012) find that developing strong customer relationships can lead to better innovative capabilities for local firms. Based on these arguments, we propose:

H2: $\quad$ In international customer-supplier relationships, the level of control held by the international customer is positively related to the local supplier's innovativeness. 


\subsection{The influence of technological uncertainty on supplier innovativeness}

Technological uncertainty is defined as the degree of volatility, change, and unpredictability related to technology in a supplier's cross-border customer-supplier relationships with its international customers (Lee et al. 2008). The importance of the organization's environmental context for innovation is generally well acknowledged (Kimberly and Evanisko 1981; Mathews 2006; Souder et al. 1998). RDT argues that managers interpret demands and dependencies in their environment prior to forming strategies and making adjustments to organizational strategies (Hillman et al. 2009; Pfeffer and Salancik 1978). This study argues that suppliers adopt more innovative actions to adapt to, and take advantage of, opportunities provided by technological uncertainty. Unpredictable changes in the technological environment quickly render existing technology obsolete, resulting in a shorter product life cycle. Hence, unpredictability of technology causes risks and uncertainties in the making of specific innovation investments. However, under greater technological uncertainty, suppliers must become more innovative to stay ahead of their competitors. This is particularly relevant for firms from emerging markets, where the technological environment changes frequently and new technology such as the Internet has created great opportunities for identifying potential customers. Hence, suppliers from emerging markets tend to be proactive and risk taking and develop innovative capabilities under unpredictable, changing technology. Empirical evidence shows that a turbulent environment makes technological firms adopt more innovative strategies because such an environment triggers the "unlearning" of current routines and offers novel opportunities for firms to take advantage of emerging market needs ( $\mathrm{Li}$ and Atuahene-Gima 2001). Hence, this study predicts the following:

H3: In international customer-supplier relationships, technological uncertainty is positively related to local suppliers' innovativeness.

\subsection{The impact of supplier innovativeness on customer dependence and relationship performance}

Prior research links innovation with power (Ibarra 1993). However, empirical evidence on the influence of innovation on power-dependence in an exchange relationship is very limited. RDT (Pfeffer and Salancik 1978) is a systematic way of examining the dynamics of bargaining power between two organizations, and has normative implications for how one organization can reduce its dependence on another. According to RDT (Pfeffer and Salancik 1978), innovation is 
an indicator of the exercise of power. The theory assumes that a firm may become a more critical resource for exchange parties when it adopts more innovative approaches. For example, if a supplier can provide a more innovative business solution to the customer, this can create a bonding effect and reduce the opportunities for a customer to switch to another supplier. Prior works on innovation in MNE-subsidiary relationships argue that subsidiaries' innovative capabilities can enhance their bargaining power and the headquarters' dependence (Kumaraswamy et al. 2012). Accordingly, an innovative supplier can change the balance of power in the exchange relationship and increase the customer's dependence. This is particularly true for emerging market supplying firms facing great pressure to upgrade their capabilities in global value chains. Therefore,

H4: In international customer-supplier relationships, local supplier innovativeness is positively related to customer dependence.

\subsection{The impact of supplier innovativeness on relationship performance}

An innovative supplier has the ability to create a better relationship with its customer. An innovative supplier can provide better product quality or deliver better products and services in a timely manner, which enhances the effectiveness and efficiency of the exchange relationship. An innovative supplier can also gain more business opportunities to work with international customers because a supplier's innovative capability builds its reputation. For example, HTC, a Taiwanese contract manufacturer with great innovative capability in providing the new generation of smart phones, has built up strong relationships with a variety of international customers. According to the RBV (Menguc and Auh 2006), innovative capability can be viewed as a dynamic capability that can enable firms to better sense their uncertain environment and become more responsive to increasing customer demands. Prior studies relate organizational innovativeness to firm performance. Hence,

H5: In international customer-supplier relationships, local supplier innovativeness is positively related to relationship performance.

\subsection{The impact of customer dependence on relationship performance}

Although suppliers act as vital connective nodes in supply networks (Andersen and Christensen 2005), they are usually more dependent on the international customer than their international customers are dependent on them. When dependence is unilateral, the international 
customer has more power over the supplier than vice versa. In such a relationship, the more powerful party is likely to contribute less to the exchange relationship, which in turn will trigger more opportunistic behaviors and damage relationship performance. In contrast, when an exchange relationship exhibits high interdependence, both parties rely equally on each other for critical resources or key assets. This makes the relationship more balanced and harmonious. This is in line with RDT, which suggests that firms develop resource interdependence for critical resources based on the advantages derived from them (Hillman et al. 2009). Lusch and Brown (1996) empirically examine the impact of dependence structures on relationship performance and find that unilateral dependence is negatively related to performance. Similarly, Katsikeas et al. (2009) find that high interdependence enhances relationship performance in international exchange relationships. This study argues that, when the customer dependence increases, both the international customer and the supplier exchange valuable, irreplaceable resources. This makes the exchange relationship more symmetric, which in turn creates an incentive structure that deters exploitation and makes both parties view their relationship as more effective and efficient. Therefore,

H6: In international customer-supplier relationships, customer dependence is positively related to relationship performance.

\subsection{The moderating influence of knowledge distance on supplier innovativeness, customer dependence and relationship performance}

As discussed in the previous section, the knowledge gaps between exchange parties' countries of origin are expected to influence the outcomes of supplier innovativeness. In terms of the link between supplier innovativeness and customer dependence, knowledge distance is likely to have a negative moderating effect on the proposed relationships for the following reasons. First, knowledge distance creates uncertainties for firms in the exchange relationship. According to RDT, the customer will rely less on supplier innovativeness as the difference in the knowledge base between the exchange parties grows, in order to mitigate uncertainties. In addition, knowledge is likely to be shared and utilized more effectively between exchange parties with similar knowledge bases. For example, in an exchange relationship characterized by high knowledge distance, such as a Taiwanese supplier (weak knowledge base) in a relationship with a US MNE customer (strong knowledge base), the powerful customer is less likely to be dependent on the weak supplier and may look for alternative suppliers with strong knowledge 
bases to perform innovative activities. This is particularly salient for international customers dealing with suppliers from emerging markets because underdeveloped institutional environment frameworks like weak IPR protection may exacerbate the potentially opportunistic behavior of emerging market suppliers, impeding their innovation generation. Prior work on MNEs' management of global innovation with their in-house subsidiaries highlights the importance of national innovation systems for the choice of location of subsidiaries for innovative tasks (Kumaraswamy et al. 2012; Luo et al. 2011). MNEs tend to choose innovative subsidiaries located in countries with similar institutional frameworks. We extend this perspective to global supply chain networks. That is, we expect that, in an exchange relationship characterized by high knowledge distance, the customer is less likely to be dependent on supplier innovativeness.

In a similar vein, we argue that the link between supplier innovativeness and relationship performance is likely to be negatively moderated by knowledge distance. That is, the positive relationship between supplier innovativeness and relationship performance is weakened under high knowledge distance between exchange partners. The absorptive capacity perspective suggests that prior possession of relevant knowledge and skill can help firms integrate and absorb new knowledge (Cohen and Levinthal 1990). Drawing on this perspective, empirical evidence shows that technology firms that are lagging in terms of technological capability may not be able to conduct knowledge-intensive FDI (Berry 2006). While the influence of knowledge distance on firms' FDI strategies has been discussed in prior work, the impact of knowledge distance on innovation in cross-border exchange relationships has not been addressed in the literature. We extend these arguments and suggest that similar knowledge bases (short knowledge distance) can help firms to better absorb and integrate new knowledge from their foreign partners, which in turn enhances firms' relationship performance. In contrast, when exchange parties face high knowledge distance, suppliers may not be able to effectively tap into foreign knowledge and reap so many benefits. This may weaken the positive link between supplier innovativeness and performance, particularly for emerging market firms that may lack appropriate levels of absorptive capacity to assimilate and develop new knowledge and reap benefits in terms of innovation. Prior research also shows that institutional distance can deter coordination and communication efforts between different units of companies (Gaur et al. 2007). Extending this perspective to innovativeness in the international customer-supplier relationship context, we argue that innovativeness will be less productive when knowledge distance is high 
because coordination becomes more challenging in the face of high knowledge gaps between exchange partners.

Finally, we also expect the relationship between customer dependence and relationship performance to be affected by the knowledge distance in the exchange relationship. Under high knowledge distance, suppliers may be in relationships with technology-leading firms that possess a stronger technology knowledge base and are more likely to exercise their bargaining power. Accordingly, it will be more difficult to appropriate rents from the customer, given the dependence of supplying firms under high knowledge distance. In contrast, under low knowledge distance, the knowledge base and bargaining power will be closer among the exchange parties. Thus, customer dependence is more likely to generate relationship performance. We sum up the moderating hypotheses as follows:

H7a: In international customer-supplier relationships, knowledge distance has a negative moderating effect on the link between local supplier innovativeness and customer dependence.

H7b: In international customer-supplier relationships, knowledge distance has a negative moderating effect on the link between local supplier innovativeness and relationship performance.

H7c: In international customer-supplier relationships, knowledge distance has a negative moderating effect on the link between customer dependence and relationship performance.

\section{Method}

\subsection{Unit of analysis}

This study examines the specific cross-border relationship between Taiwanese suppliers and their international OEMs. This was a deliberate choice as Taiwanese suppliers tend to be smaller than their international OEM customers, and thus these relationships usually show power asymmetry. Furthermore, the Taiwanese electronics industry offers a valuable empirical context because its industry members have served as pioneers in information technology development, have championed cross-border relationships with US and European industry leaders, and are actively participating in the world economy (Dedrick et al. 2007). Taiwanese suppliers compete fiercely for contracts and cross-border exchange relationships with leading MNEs such as IBM, HP, and Dell. Subcontracted activities may include product development, manufacturing, and 
advanced product innovation and design (Pete et al. 2005; Quinn 2000). For MNEs, this move towards outsourcing traditional upstream value-chain activities is significant, as it promises performance benefits and advantages over competitors. Hence, the disintegration of international supply chains is an important strategic feature in this market.

\subsection{Sampling frame and data collection}

Senior account and marketing managers directly involved in international OEM relationships with branded firms are chosen as the key informants in this study. A survey methodology was used to collect the data. The sampling frame constitutes all electronic companies from the year 2007 directory of the Top 5000 Largest Firms in Taiwan, published by China Credit Information Service Ltd (1069 companies). All firms in the database were contacted to assess their eligibility and to locate appropriate informants for the study.

Respondents were asked to specify the most important international OEM customers in terms of the largest sales volume. This was seen as critical to the investigation of the asymmetric nature of cross-border relationships in this study. Approximately three quarters of the sales of the suppliers in our sample were derived from a single most important OEM customer.

Data collection was conducted in two stages. In-depth interviews were first conducted with fifteen senior account and marketing managers or directors of Taiwanese suppliers. This initial qualitative and exploratory approach provided valuable inputs for questionnaire refinement and the adaptation of key constructs to the current industry context. These interviews served as an a priori test of the key constructs with respect to usefulness and appropriateness. In the second stage, the final survey instrument was mailed out to Taiwanese electronics companies from the directory. Yu and Cooper's (1983) suggestions for maximizing response rates were applied, and multiple contact points (Dillman 2000) via telephone and personal contacts were established to solicit responses to the study. Questionnaires were also sent via e-mail to accommodate respondents' preferences regarding response options. For the telephone and e-mail surveys, each informant who agreed to participate in this study was faxed or emailed a questionnaire packet. 


\subsection{Survey response and informant evaluation}

A total of 246 useable questionnaires were returned (13 unsuitable), resulting in an effective response rate of $23.29 \%$ (246/1056). Table 1 represents the respondents' characteristics. The international OEM customers named by the suppliers in the dataset were from the USA, Japan, Germany, China, and France. Taiwanese electronics suppliers are involved in the supply of computer components, semiconductors, communication products, computer peripherals, and optoelectronics. Over $67 \%$ of Taiwanese suppliers are small and medium-sized (i.e. with less than 250 employees). The survey instrument used in this study made it possible for us to identify the level of the supplier's dependence on the international OEM customers, both in terms of resource endowment and potential to be replaced with another customer.

We assess non-response bias by classifying responses into two groups, early respondents and late respondents (Armstrong and Overton 1977). Independent t-tests on demographic variables such as revenue and employee numbers are performed. No significant differences are identified for these descriptive variables between early (first 25\%) and late (last 25\%) respondents. Furthermore, t-tests are conducted on key variables in the proposed conceptual model, such as technological uncertainty and supplier innovativeness, between these two groups. Again, no significant differences emerge.

A reliable assessment of non-response bias can only be achieved via feedback from the non-respondents themselves. Therefore, we identified a selection of non-respondents and called them to obtain explanations for their lack of response. In all cases, the reasons provided to us were related to time pressures in filling out the questionnaire and the general notion that the questionnaire was too demanding and other requests for feedback had to be prioritized. These findings imply that non-response bias does not pose a significant threat to the study.

Insert Table 1 here 


\subsection{Measurement}

Multi-item scales and a seven-point response format were used to operationalize all constructs and variables in the study. The measures were adapted from existing studies and refined based on feedback from experienced researchers and practitioners in the area of inquiry.

Customer orientation scales were adapted from Deshpandé et al. (1993), to measure the organizational culture that most effectively and efficiently creates the necessary behaviors for the creation of superior value for the customer. International customer control measures the extent to which a responding firm influences its supplier's production processes, engineering changes, level of inventory, choice of suppliers and quality control process (Heide et al. 2007; Ryu and Eyuboglu 2007). Scales for international customer control were borrowed from Ryu and Eyuboglu (2007). Technological uncertainty was conceptualized so as to capture product complexity, technological innovation, and the rate of technological change in the industry (Celly et al. 1999). It was adapted from the technological turbulence scale of Celly et al. (1999) and Jaworski and Kohli (1993). Supplier's organizational innovativeness was operationalized as the ability to introduce new ideas and technology into the industry and to deliver unique service offerings and innovativeness in the supply chain (Hult et al. 2007). This dimension was measured with a five-item scale, adapted from the work of Hurley and Hult (1998). Customer dependence was measured by the supplier's perception of the extent to which its international customer depended on it. Our operationalization of relationship performance was drawn from existing literature (Liu et al. 2009; Selnes and Sallis 2003) and measure the extent to which suppliers' performance in terms of sales growth, market share, profitability, product quality and opportunities are generated from relationship with the international customer. We believe the operationalization of firm performance at the relationship level is important in maintaining the unit of analysis while remaining plausible theoretically.

Knowledge distance refers to the knowledge gaps between the Taiwanese supplier and its most important international customers. According to Bell et al. (2009), we measured knowledge distance by calculating the sum of the difference between the number of patents and scientific articles of the two exchange partners' countries of origins. We used the number of Science Citation Index (SCI) publications by country, obtained from www.scimagojr.com, and the number of patents granted by country, obtained from the World Intellectual Property 
Organization (i.e., wipo.int). We collected these data for the time of our survey data collection for internal consistency. Since knowledge distance serves as a moderator, we constructed a composite index of those two variables.

Furthermore, firm size is included as a control variable to control for the effect of a supplier's business scale on its innovativeness and performance.

\subsection{Measurement model results}

Confirmatory factor analysis (CFA) was performed using EQS for Windows 6.1 to evaluate the measurement model. The CFA model included all six study constructs: customer orientation, customer control, technological uncertainty, organizational innovativeness, customer dependence, and relational performance. To purify the measures, items with a loading of less than .5 were eliminated to increase convergent validity. Furthermore, item scales linked to more than one construct were removed to improve discriminant validity. The purification process resulted in at least three items for each construct. As Table 2 shows, the final CFA model revealed a good fit with the covariances provided by the dataset, with $\chi^{2}=436.31$ on 237 d.f., $\mathrm{NNFI}=.938, \mathrm{CFI}=.947$, and RMSEA $=.059($ Bentler and Chou 1987).

The unidimensionality of the constructs was assessed by examining convergent validity and discriminant validity. All items load significantly on their corresponding factor $(\mathrm{p}<.01)$ and their loadings are greater than .5, as shown in Table 2. This indicates an adequate level of convergent validity (Nunnally and Bernstein 1994). For discriminant validity, the average variance extracted (AVE) of each construct should be greater than its shared variances (Fornell and Larcker 1981). The AVE for each construct ranges from .54 to .90, while the shared variances among the constructs range from .02 to .25 , as reported in the upper triangle of Table 3. These results demonstrate a good level of discriminant validity between the constructs in this study (Fornell and Larcker 1981). Table 2 reports the composite reliability of each construct along with the standardized parameters of the measurement items. All composite reliabilities are greater than .86 , far above the acceptable level of .7 discussed in the literature (Nunnally and Bernstein 1994).

Insert Table 2 and Table 3 here 


\subsection{Common method bias assessment}

All the measures in this study, except for cultural difference, were collected via a single questionnaire. Therefore, some degree of common method bias may exist in our survey data. A rigorous approach was adopted to test for common method bias by using hierarchically nested covariance structure models (e.g. Cote and Buckley 1987). Three models were tested: a trait only model (M2), a method only model (M3), and a trait and method model (M4). The results in Table 4 show that variances from construct items (or traits) exist but those from the method are weakly present ( $\mathrm{p}>.01)$. To assess the extent to which such method variances are present, we calculated the mean percentages of variance explained by the construct items and by the common method factor. The results show that the mean percentage of variance explained by the construct items is $67.4 \%$ while that of the common method factor is only $6.9 \%$, indicating that common method bias is minor. Therefore, common method bias does not pose a major threat to the study.

\section{Insert Table 4 here}

\section{Analysis and results}

\subsection{Structural model}

To test hypotheses 1 through 6 , the proposed model with all measurement items from the CFA model along with cultural difference in the masculinity dimension was estimated, using EQS for Windows 6.1. In this estimation, we added a control variable, firm size, as the logtransformed number of employees, to control for the effects of a firm's business scale on performance. The results reveal a good fit of the model with the empirical covariances provided by the data, with $\chi^{2}=538.46$ on 266 d.f., NNFI $=.918, \mathrm{CFI}=.927$, and RMSEA $=.065$. Based on the good fit of the structural model, the proposed hypotheses 1 through 6 were tested.

In Hypothesis 1 we claimed that customer orientation, that is, the supplier's organizational environment, leads to the enhancement of organizational innovativeness between the supplier and its international customer, and this is supported $(b=.419, \mathrm{p}<.01)$. We also contended in Hypothesis 2 that the level of customer control improves organizational innovativeness and this is also supported $(b=.185, p<.01)$. In Hypothesis 3 , we maintained that 
technological uncertainty, that is, the market environment, results in improved organizational innovativeness. It too is supported $(b=.140, \mathrm{p}<.05)$.

Regarding the outcomes of supplier innovativeness, the study offered Hypothesis 4, which argues that organizational innovativeness increases customer dependence. The results lend support to the hypothesis $(\mathrm{b}=.419, \mathrm{p}<.01)$. In Hypothesis 5 , supplier innovativeness is related to relationship performance positively and this is supported as well $(b=.420, p<.01)$. Finally, MNE customer dependence was expected to help improve relationship performance in Hypothesis 6. This hypothesis is supported by the results $(b=.179, \mathrm{p}<.05)$. Figure 2 summarizes the results of the hypothesis testing.

We also conducted a two-group analysis to assess the moderating role of knowledge distance between the suppliers and customers. We median-split the sample into two groups based on the composite index of the total number of patents and SCI publications. Before conducting the two-group analysis, we assessed the measurement invariance between the groups (Schmitt and Kuljanin 2008; Steenkamp and Baumgartner 1998; Vandenberg 2002; Vandenberg and Lance 2000). As suggested by Steenkamp and Baumgartner (1998), we carried out three types of invariance tests that are required in order to compare the standardized path coefficients between groups, namely, configural invariance, metric invariance, and variance invariance. According to the results of the measurement invariance tests, the configural invariance is supported for the two-group analysis because the combination of significantly loaded items is consistent in both groups, all factor loadings are significantly and substantially different from zero, and the factor correlations are significantly below unity across all groups (Steenkamp and Baumgartner 1998; Vandenberg and Lance 2000). Subsequently, metric invariance was assessed. According to the results, all of the study constructs show full metric invariance $(p>.05)$ between groups except for the technology uncertainty construct with one item that is not invariant $((p>.05)$. However, only partial metric invariance is required to compare the standardized coefficients between the groups, according to the literature (Steenkamp and Baumgartner 1998). Since technology uncertainty has another two items, apart from the scale item, which are metrically invariant between the groups, it meets the requirement for partial metric invariance. Because partial metric invariance is a sufficient condition for a two-group comparison of standardized coefficients (Steenkamp and Baumgartner 1998), we proceeded with the multiple-group analysis. 
With the measurement variances invariant for the purpose of this study, a two-group analysis with two separate samples was carried out, with equal constraints on all seven paths, including those three paths that were hypothesized to be moderated by knowledge distance. The equal constraints allowed us to carry out chi-square difference tests to evaluate whether or not each path was statistically significantly different between the two groups. The results of the initial estimation indicate that the chi-square differences on the paths between supplier innovativeness and relational performance $\left(\Delta \chi^{2}=5.539\right)$ and customer dependence and relationship performance $\left(\Delta \chi^{2}=5.539\right)$ are significant between the two groups, supporting H7b and H7c. Subsequently, we released those paths and re-estimated the model. The results show that no further paths are significantly moderated by knowledge distance. Therefore, H7a is not supported. The results suggest that innovativeness is positively related to customer dependence under both high and low knowledge distance. Furthermore, the fit indexes of the final two-group model indicate a good fit of the model with the covariances provided by the data, with $\chi^{2}=$ 901.39 on 537 d.f., NNFI $=.893, \mathrm{CFI}=.905$, and RMSEA $=.075$ (Bentler and Chou 1987), as reported in Figure 3.

\section{Discussion}

With the increase in global innovation outsourcing and a significant shift towards supplier-driven international innovation networks, suppliers are now playing key roles in their respective networks (Andersen and Christensen 2005) and in global innovation (Johnsen et al. 2006). This study investigates how suppliers can enhance organizational innovativeness in crossborder customer-supplier relationships with OEM customers and the influence this has on the dependence structures and relationship performance. Drawing on RDT, the RBV and the institutional aspect of cross-national distance, this study develops and empirically tests an integrative model that delineates the antecedents and performance outcomes of supplier innovativeness in cross-border customer-supplier relationships. In terms of the international/cross-border dimension, this study focuses particularly on knowledge distance in the exchange relationship and the moderating effect of these differences on supplier innovativeness and relationship performance. The empirical context is Taiwanese supply firms in relationships with MNE customers. This study broadens and deepens our understanding of how 
emerging country suppliers can develop innovative capability and create competitiveness in international exchange relationships.

\subsection{Theoretical implications}

The results of this study show that supplier innovativeness enhances international customer dependence and relationship performance. This finding sheds light on the interrelationships between innovation, power, and performance in exchange relationships. Supplier innovativeness, a critical organizational resource and capability, can serve as a balancing strategy that increases the customer's dependence. This in turn, enhances relationship performance in international exchange relationships. Prior work on the management of global innovation focuses primarily on how subsidiaries' innovative capabilities serve as a power source and change interdependent relationships with MNEs (Kumaraswamy et al. 2012). This study extends this perspective to the global supply chain context and suggests that contracting suppliers can also leverage their innovative capabilities as a dependence-balancing strategy in their relationships with their MNE customers. In addition, the link between supplier innovativeness and customer dependence is found to be significant when knowledge bases differ. Overall, this study makes a unique contribution by extending innovation management research in the field of international business. Further, this study complements the RBV and RDT by offering new insight into how obtaining control of critical resources and developing innovative capability offers firms a competitive advantage in the exchange relationship, not only in terms of achieving desirable relationship performance but also in terms of enhancing their bargaining power in relation to their partner. The RBV has been focused internally on how firms specify resources to create competitive advantage. In contrast, RDT has focused more externally on how firms obtain critical resources from an uncertain environment. Following Hillman et al. (2009), because of the complementary focus on resources, integrating these two theories may advance theoretical development.

The results of this study support prior research on the antecedents to cross-border supplier-driven innovation, showing that the supplier's customer orientation, the international customer's control, and the technological uncertainty between exchange parties enhance the supplier's innovativeness in international customer-supplier relationships. Moreover, the supplier's customer orientation has the strongest effect on the development of the supplier's 
organizational innovativeness, followed by the international customer's control, and technological uncertainty.

The strength of the effect of customer orientation on the supplier's innovativeness reinforces the importance of developing a customer-oriented organizational culture to enhance innovative capability, for suppliers in international exchange relationships. Compared with other drivers of supplier innovation, the strongest effect exhibited by customer orientation implies that organizational culture is the best catalyst for innovation. This is consistent with Tellis et al.'s (2009a) recent findings confirming that corporate culture is the strongest driver of radical innovation.

This study further demonstrates that international customer control over the supplier can contribute to the supplier's innovativeness. In contrast to previous studies, which indicate a negative effect of control on innovation and creativity, the empirical evidence in this study suggests that supplier-driven innovation may require an appropriate level of customer control. Customer control provides leadership and guidance, which makes the innovation process more effective and efficient. This is consistent with Henke and Zhang's (2010) recent study, which highlights customer support as a key driver of supplier-driven innovation in supply chain relationships.

The results further demonstrate that technological uncertainty may actually enhance supplier innovativeness. An explanation can be found in the fact that proliferating technology is stimulating new product creativity. This finding is in line with the results of recent research showing that headquarters and subsidiaries may transfer knowledge more readily so as to stay abreast of the current technology, thus enhancing new product creativity and performance (Lee et al. 2008). These results confirm the importance and value of supplier-driven innovation in the presence of frequent technological changes and updates in the industry.

Our results also reveal that cross-national differences, specifically differences in the knowledge base between the supplier and its international customer, shape the strength of the effects of supplier innovative capability and customer dependence on relationship performance. For a supplier, dealing with an international MNE customer from whom there is a high knowledge distance is not conducive to benefits being reaped from the supplier's innovativeness and advantage being taken of the customer's dependence. This finding is consistent with research 
on the influence of knowledge gaps on knowledge-intensive FDI, which notes that technologylagging firms may not benefit much from investing in technology-advanced countries, due to gaps in their knowledge bases (Guler and Guillén 2010). The implication of this result is that, while supplying firms from emerging countries try to tap into knowledge from developed countries, the knowledge gaps between the exchange parties, and suppliers' weak absorptive capability, may pose challenges to knowledge transfer and integration, which in turn hamper the benefits of innovativeness. In addition, under high knowledge distance, customers may be more likely to exercise their power and appropriate more benefits from the supplying firms' innovativeness. This finding is consistent with a recent argument suggesting that international technology collaboration arrangements seem unable to provide sufficient and satisfactory benefits for technology catch-ups from emerging markets. For example, Nam's (2011) study shows that international joint ventures in China may not be a preferred model for developing Chinese auto makers' technology innovation and performance. Western technology leaders may exercise their power gained from knowledge gaps against emerging firms and expropriate more benefits from collaborative arrangements. Prior work on the management of global innovation argues that knowledge gaps between MNEs and the location of their innovative subsidiaries may hamper knowledge flows and innovation outputs. Our findings extend this view to global supply chain contexts and suggest that knowledge gaps originating from the differing institutional frameworks of the countries of an exchange relationship can also deter innovation generation by contracting suppliers in global supply chain relationships.

Drawing on emerging work on institutional aspects of knowledge distance among different countries, this study sheds light on the impact of cross-national differences on firm innovativeness and, eventually, firm performance (Rosenbusch et al. 2011). The results suggest that institutional differences, in terms of a country's innovation systems, may also shape the outcomes of innovation. Prior work focuses more on examining the institutional framework's impact on MNEs' in-house innovation networks with subsidiaries. Our work extends prior studies by showing how institutional environment differences in terms of knowledge can shape innovation generation for MNEs and their offshoring suppliers. Further, in contrast to prior work focusing more on the influence of national culture on firm innovation, researchers might pay more attention to the impacts of institutional differences on cross-border innovation, particularly in the context of global supply chains. Our findings show that institutional differences can shape 
firms' innovativeness capabilities as well as their performance in emerging markets. This research also contributes to the growing literature on the theoretical integration between the RBV and the institutional framework (Cuervo-Cazurra and Genc 2011). Future studies can extend our work by examining the effects of other institutional differences, such as legal and regulatory differences, on supplying firms' resources, capabilities, and the resultant firm performance.

\subsection{Managerial implications}

The findings of this study provide managers with novel insights regarding the strategy for developing supplier innovativeness in the global market. The results show that both suppliers and international customers can help drive suppliers' innovative capabilities. A supplier's internal customer orientation plays the most important role in enhancing the supplier's innovativeness. Hence, suppliers in emerging markets should be proactive in developing their customer orientation so as to enhance their innovative capabilities. In addition, the customer should provide necessary and sufficient support to control the supplier's product and innovation processes in the global innovation network. The results also show that innovativeness is a critical resource that allows suppliers to stay ahead of the competition by increasing their bargaining power and enhancing their relationship effectiveness and efficiency. Innovativeness is a dependence-balancing strategy that suppliers can use to appropriate rents from their relationships with demanding global customers. Further, for policy makers who are striving to develop technology innovativeness among emerging market firms, the findings suggest that they need to be cautious about international technology transfer issues, due to knowledge distances between exchange parties, originating from differences in countries' knowledge bases. Policy makers need to strengthen nations' innovation systems by working with different institutional actors, such as by forming associations between universities and the government. Through the upgrading of a country's innovation capability and, therefore, the reduction of knowledge gaps, emerging market suppliers can be enabled to reap more benefits from their innovative efforts. Consequently, managers in supplying firms may need to evaluate the institutional differences between exchange parties carefully in order to reap greater benefits from their innovative capabilities. 


\section{Limitations and further research}

The results of this study should be interpreted in light of several inherent limitations. First, supplier innovativeness was measured using subjective measurement. Future studies should also include objective measures of supplier innovation, such as patents or R\&D expenditure. This study collects some supplier patent data from public datasets, and reveals some correlations between patent counts and supplier innovativeness, but the number of observations was relatively small. Our efforts point at good potential for future research to use other objective innovation indicators to measure supplier-driven innovation in the international innovation network. Further, our study incorporated cross-cultural knowledge distance at the country level. Future studies can develop reliable and validated scales to measure the perception of knowledge differences at the (inter) firm level.

In terms of methodology, this study relies on data collected from Taiwanese OEM suppliers. Due to the limited scope of this sample, it is difficult to generalize our findings to other international customer-supplier relationships, especially in other industrial contexts. Future research should thus consider obtaining data from other industries and both customers and their suppliers to cross-check the validity of the proposed model. This may prove very challenging, as the identity of the customer is very sensitive information in this type of international relationship. Overcoming these obstacles would provide a contribution to our thorough understanding of innovation generation in international supply chains. Furthermore, this study only adopts a single-respondent strategy, which may have produced a common method bias. While we have carefully assessed such possible biases, future research should collect data using multiple respondents for each organization under study.

Another limitation of this study is its cross-sectional design. Although the results of this study reveal the antecedents and performance outcomes of supplier innovativeness, causality is only implied. Future studies could overcome this limitation using longitudinal data collection, even if only for relatively short periods.

\section{Conclusion}

As global competition intensifies, MNEs continue to develop new products more quickly and add sophisticated innovations through collaborations with their external suppliers. With most 
supplying firms located in emerging markets, those suppliers face great challenges in developing innovative capabilities to serve their international customers due to weaker levels of absorptive capacity and underdeveloped institutional infrastructure in emerging markets. Drawing on the RBV, RDT, and the institutional aspect of knowledge distance, this study investigated several dimensions of antecedents of suppliers' innovative capability and its performance implications. This study contributes to the growing literature on the integration of institutional theory with organization and strategy theory. Overall, this study provides a strong theoretical and empirical foundation for understanding how suppliers from emerging markets can augment innovation capability in cross-border exchange relationships and improve performance outcomes.

\section{References}

Andersen, P. H., \& Christensen, P. R. (2005). Bridges over troubled water: Suppliers as connective nodes in global supply networks. Journal of Business Research, 58(9), 12611273.

Armstrong, J. S., \& Overton, T. S. (1977). Estimating nonresponse bias in mail surveys. Journal of Marketing Research, 14(3), 396-402.

Atuahene-Gima, K. (2005). Resolving the capability-rigidity paradox in new product innovation. Journal of Marketing, 69(4), 61-83.

Azadegan, A., \& Dooley, K. J. (2010). Supplier innovativeness, organizational learning styles and manufacturer performance: An empirical assessment. Journal of Operations Management, 28(6), 488-505.

Barney, J. B. (1991). Firm resources and sustained competitive advantage. Journal of Management, 17(1), 99-121.

Bell, S. J., Tracey, P., \& Heide, J. B. (2009). The organization of regional clusters. Academy of Management Review, 34(4), 623-642.

Bello, D. C., Chelariu, C., \& Zhang, L. (2003). The antecedents and performance consequences of relationalism in export distribution channels. Journal of Business Research, 56(1), 116.

Bentler, P. M., \& Chou, C.-P. (1987). Practical issues in structural modeling. Sociological Methods Research, 16(1), 78-117.

Berry, H. (2006). Leaders, laggards, and the pursuit of foreign knowledge. Strategic Management Journal, 27(2), 151-168.

Berry, H., Guillén, M. F., \& Zhou, N. (2010). An institutional approach to cross-national distance. Journal of International Business Studies, 41(9), 1460-1480.

Blocker, C., Flint, D., Myers, M., \& Slater, S. (2010). Proactive customer orientation and its role for creating customer value in global markets. Journal of the Academy of Marketing Science, 1-18.

Cantwell, J., \& Janne, O. (1999). Technological globalisation and innovative centres: The role of corporate technological leadership and locational hierarchy. Research Policy, 28(2-3), 119-144. 
Carson, S. J. (2007). When to give up control of outsourced new product development. Journal of Marketing, 71(1), 49-66.

Celly, K. S., Spekman, R. E., \& Kamauff, J. W. (1999). Technological uncertainty, buyer preferences and supplier assurances: An examination of Pacific rim purchasing arrangements. Journal of International Business Studies, 30(2), 297-310.

Chang, K.-H., \& Gotcher, D. F. (2007). Safeguarding investments and creation of transaction value in asymmetric international subcontracting relationships: The role of relationship learning and relational capital. Journal of World Business, 42(4), 477-488.

Cohen, W. M., \& Levinthal, D. A. (1990). Absorptive capacity: A new perspective on learning and innovation. Administrative Science Quarterly, 35(1), 128-152.

Cote, J. A., \& Buckley, M. R. (1987). Estimating trait, method, and error variance: Generalizing across 70 construct validation studies. Journal of Marketing Research, 24(3), 315-318.

Cuervo-Cazurra, A., \& Genc, M. E. (2011). Obligating, pressuring, and supporting dimensions of the environment and the non-market advantages of developing-country multinational companies. Journal of Management Studies, 48(2), 441-455.

Cui, A. S., \& O'Connor, G. (2012). Alliance portfolio resource diversity and firm innovation. Journal of Marketing, 1-19.

Dedrick, J., Kraemer, K. L., Linden, G., Brown, C., \& Murtha, T. (2007). Organizing global knowledge networks in the electronics industry. Irvine, CA: Personal Computing Industry Center.

Deshpandé, R., Farley, J. U., \& Bowman, D. (2004). Tigers, dragons, and others: Profiling high performance in asian firms. Journal of International Marketing, 12(3), 5-29.

Deshpandé, R., Farley, J. U., \& Webster Jr., F. E. (1993). Corporate culture customer orientation, and innovativeness in Japanese firms: A quadrad analysis. Journal of Marketing, 57(1), 23-37.

Dillman, D. A. (2000). Mail and internet surveys: The tailored design method. New York, NY: John Wiley \& Sons.

Fornell, C., \& Larcker, D. F. (1981). Evaluating structural equation models with unobservable variables and measurement error. Journal of Marketing Research, 18(1), 39-50.

Frambach, R. T., \& Schillewaert, N. (2002). Organizational innovation adoption: A multi-level framework of determinants and opportunities for future research. Journal of Business Research, 55(2), 163-176.

Furman, J. L., Porter, M. E., \& Stern, S. (2002). The determinants of national innovative capacity. Research Policy, 31(6), 899-933.

Gatignon, H., \& Xuereb, J.-M. (1997). Strategic orientation of the firm and new product performance. Journal of Marketing Research, 34(1), 77-90.

Gaur, A. S., Delios, A., \& Singh, K. (2007). Institutional environments, staffing strategies, and subsidiary performance. Journal of Management, 33(4), 611-636.

Guler, I., \& Guillén, M. F. (2010). Institutions and the internationalization of US venture capital firms. Journal of International Business Studies, 41(2), 185-205.

Han, J. K., Kim, N., \& Srivastava, R. K. (1998). Market orientation and organizational performance: Is innovation a missing link? Journal of Marketing, 62(4), 30-45.

Heide, J. B., Wathne, K. H., \& Rokkan, A. I. (2007). Interfirm monitoring, social contracts, and relationship outcomes. Journal of Marketing Research, 44(3), 425-433.

Henke, J. W. J., \& Zhang, C. (2010). Increasing supplier-driven innovation. Sloan Management Review, 51(2), 41-46. 
Hillman, A. J., Withers, M. C., \& Collins, B. J. (2009). Resource dependence theory: A review. Journal of Management, 35(6), 1404-1427.

Hilmola, O. P., Helo, P., \& Holweg, M. (2005). On the outsourcing dynamics in the electronics sector: The evolving role of the original design manufacturer. University of Cambridge, Working Paper Series(04)

Hofstede, G. (1984). Culture's consequences: International differences in work-related values. (Cross-cultural research and methodology series). Newbury Park, CA.: Sage Publications.

Hult, G. T. M., Ketchen, D. J., \& Arrfelt, M. (2007). Strategic supply chain management: Improving performance through a culture of competitiveness and knowledge development. Strategic Management Journal, 28(10), 1035-1052.

Hurley, R. F., \& Hult, G. T. M. (1998). Innovation, market orientation, and organizational learning: An integration and empirical examination. Journal of Marketing, 62(3), 42-54.

Ibarra, H. (1993). Network centrality, power, and innovation involvement: Determinants of technical and administrative roles. The Academy of Management Journal, 36(3), 471-501.

Jansen, J. J. P., Van Den Bosch, F. A. J., \& Volberda, H. W. (2006). Exploratory innovation, exploitative innovation, and performance: Effects of organizational antecedents and environmental moderators. Management Science, 52(11), 1661-1674.

Jaworski, B. J., \& Kohli, A. K. (1993). Market orientation: Antecedents and consequences. Journal of Marketing, 57(3), 53-70.

Jean, R.-J. B., Sinkovics, R. R., \& Cavusgil, S. T. (2010). Enhancing international customersupplier relationships through IT resources: A study of Taiwanese electronics suppliers. Journal of International Business Studies, 41(7), 1218-1239.

Johnsen, T., Phillips, W., Caldwell, N., \& Lewis, M. (2006). Centrality of customer and supplier interaction in innovation. Journal of Business Research, 59(6), 671-678.

Joshi, A. W., \& Sharma, S. (2004). Customer knowledge development: Antecedents and impact on new product performance. Journal of Marketing, 68(4), 47-59.

Kang, M.-P., Mahoney, J. T., \& Tan, D. (2009). Why firms make unilateral investments specific to other firms: The case of OEM suppliers. Strategic Management Journal, 30(2), 117 135.

Katsikeas, C. S., Skarmeas, D., \& Bello, D. C. (2009). Developing successful trust-based international exchange relationships. Journal of International Business Studies, 40(1), $132-155$.

Kim, N., \& Atuahene-Gima, K. (2010). Using exploratory and exploitative market learning for new product development*. Journal of Product Innovation Management, 27(4), 519-536.

Kimberly, J. R., \& Evanisko, M. J. (1981). Organizational innovation: The influence of individual, organizational, and contextual factors on hospital adoption of technological and administrative innovations. Academy of Management Journal, 24(4), 689-713.

Koberg, C. S., Detienne, D. R., \& Heppard, K. A. (2003). An empirical test of environmental, organizational, and process factors affecting incremental and radical innovation. The Journal of High Technology Management Research, 14(1), 21-45.

Kumaraswamy, A., Mudambi, R., Saranga, H., \& Tripathy, A. (2012). Catch-up strategies in the Indian auto components industry: Domestic firms' responses to market liberalization. Journal of International Business Studies, 43(4), 368-395. 
Lee, R. P., Chen, Q., Kim, D., \& Johnson, J. L. (2008). Knowledge transfer between multinational corporations' headquarters and their subsidiaries: Influences on and implications for new product outcomes. Journal of International Marketing, 16(2), 1-31.

Li, D., Miller, S. R., Eden, L., \& Hitt, M. A. (2012). The impact of rule of law on market value creation for local alliance partners in BRIC countries. Journal of International Management, 18(4), 305-321.

Li, H., \& Atuahene-Gima, K. (2001). Product innovation strategy and the performance of new technology ventures in China. Academy of Management Journal, 44(6), 1123-1134.

Li, J., Chen, D., \& Shapiro, D. M. (2010). Product innovations in emerging economies: The role of foreign knowledge access channels and internal efforts in Chinese firms. Management and Organization Review, 6(2), 243-266.

Liu, Y., Luo, Y., \& Liu, T. (2009). Governing buyer-supplier relationships through transactional and relational mechanisms: Evidence from China. Journal of Operations Management, 27(4), 294-309.

Luo, Y., Sun, J., \& Wang, S. L. (2011). Comparative strategic management: An emergent field in international management. Journal of International Management, 17(3), 190-200.

Lusch, R. F., \& Brown, J. R. (1996). Interdependency, contracting, and relational behavior in marketing channels. Journal of Marketing, 60(4), 19-38.

Mathews, J. (2006). Dragon multinationals: New players in 21st century globalization. Asia Pacific Journal of Management, 23(1), 5-27.

Medcof, J. W. (2001). Resource-based strategy and managerial power in networks of internationally dispersed technology units. Strategic Management Journal, 22(11), 9991012.

Menguc, B., \& Auh, S. (2006). Creating a firm-level dynamic capability through capitalizing on market orientation and innovativeness. Journal of the Academy of Marketing Science, 34(1), 63-73.

Meyer, K. E., Mudambi, R., \& Narula, R. (2011). Multinational enterprises and local contexts: The opportunities and challenges of multiple embeddedness. Journal of Management Studies, 48(2), 235-252.

Morrison, A., Pietrobelli, C., \& Rabellotti, R. (2008). Global value chains and technological capabilities: A framework to study learning and innovation in developing countries. Oxford Development Studies, 36(1), 39-58.

Nakata, C., \& Sivakumar, K. (1996). National culture and new product development: An integrative review. Journal of Marketing, 60(1), 61-72.

Nam, K.-M. (2011). Learning through the international joint venture: Lessons from the experience of china's automotive sector. Industrial and Corporate Change, 20(3), 855907.

Narver, J. C., Slater, S. F., \& MacLachlan, D. L. (2004). Responsive and proactive market orientation and new-product success. Journal of Product Innovation Management, 21(5), 334-347.

Nunnally, J. C., \& Bernstein, I. H. (1994). Psychometric theory. New York: McGraw-Hill.

Peng, M. W., Wang, D. Y. L., \& Jiang, Y. (2008). An institution-based view of international business strategy: A focus on emerging economies. Journal of International Business Studies, 39(5), 920-936.

Pete, E., Einhorn, B., \& Reinhardt, A. (2005). Outsourcing innovation. Businessweek(3925), 84. 
Pfeffer, J., \& Salancik, G. R. (1978). The external control of organizations: A resource dependence perspective London: Harper \& Row.

Pietrobelli, C., \& Rabellotti, R. (2011). Global value chains meet innovation systems: Are there learning opportunities for developing countries? World Development, 39(7), 1261-1269.

Quinn, J. B. (2000). Outsourcing innovation: The new engine of growth. Sloan Management Review, 41(4), 13-28.

Renko, M., Carsrud, A., \& Brännback, M. (2009). The effect of a market orientation, entrepreneurial orientation, and technological capability on innovativeness: A study of young biotechnology ventures in the United States and in scandinavia. Journal of Small Business Management, 47(3), 331-369.

Rosenbusch, N., Brinckmann, J., \& Bausch, A. (2011). Is innovation always beneficial? A metaanalysis of the relationship between innovation and performance in SMEs. Journal of Business Venturing, 26(4), 441-457.

Roy, S., Sivakumar, K., \& Wilkinson, I. F. (2004). Innovation generation in supply chain relationships: A conceptual model and research propositions. Journal of the Academy of Marketing Science, 32(1), 61-79.

Rubera, G., \& Kirca, A. H. (2011). Firm innovativeness and its performance outcomes: A metaanalytic review and theoretical integration. Journal of Marketing, 76(3), 130-147.

Ryu, S., \& Eyuboglu, N. (2007). The environment and its impact on satisfaction with supplier performance: An investigation of the mediating effects of control mechanisms from the perspective of the manufacturer in the U.S.A. Industrial Marketing Management, 36(4), 458-469.

Schmitt, N., \& Kuljanin, G. (2008). Measurement invariance: Review of practice and implications. Human Resource Management Review, 18(4), 210-222.

Selnes, F., \& Sallis, J. (2003). Promoting relationship learning. Journal of Marketing, 67(3), 8095.

Sheng, S., Zhou, K. Z., \& Li, J. J. (2011). The effects of business and political ties on firm performance: Evidence from China. Journal of Marketing, 75(1), 1-15.

Sinkovics, R. R., Jean, R.-J. B., \& Pezderka, N. (2010). Cross-border relationships and performance: Revisiting a complex linkage - a commentary essay. Journal of Business Research, 63(12), 1368-1371.

Souder, W. E., Sherman, J. D., \& Davies-Cooper, R. (1998). Environmental uncertainty, organizational integration, and new product development effectiveness: A test of contingency theory. Journal of Product Innovation Management, 15(6), 520-533.

Steenkamp, J.-B., \& Baumgartner, H. (1998). Assessing measurement invariance in crossnational consumer research. Journal of Consumer Research, 25(1), 78-90.

Stock, R., \& Zacharias, N. (2010). Patterns and performance outcomes of innovation orientation. Journal of the Academy of Marketing Science, 1-19.

Sultan, N. (2010). Cloud computing for education: A new dawn? International Journal of Information Management, 30(2), 109-116.

Teece, D., Pisano, G., \& Shuen, A. (1997). Dynamic capabilities and strategic management. Strategic Management Journal, 18(7), 509-533.

Tellis, G. J., Prabhu, J. C., \& Chandy, R. K. (2009a). Radical innovation across nations: The preeminence of corporate culture. Journal of Marketing, 73(1), 3-23. 
Tellis, G. J., Stremersch, S., \& Yin, E. (2003). The international takeoff of new products: The role of economics, culture, and country innovativeness. Marketing Science, 22(2), 188208.

Tellis, G. J., Yin, E., \& Bell, S. (2009b). Global consumer innovativeness: Cross-country differences and demographic commonalities. Journal of International Marketing, 17(2), $1-22$.

Vandenberg, R. J. (2002). Toward a further understanding of and improvement in measurement invariance methods and procedures. Organizational Research Methods, 5(2), 139-158.

Vandenberg, R. J., \& Lance, C. E. (2000). A review and synthesis of the measurement invariance literature: Suggestions, practices, and recommendations for organizational research. Organizational Research Methods, 3(1), 4-70.

Wang, Q., Bradford, K., Xu, J., \& Weitz, B. (2008). Creativity in buyer-seller relationships: The role of governance. International Journal of Research in Marketing, 25(2), 109-118.

$\mathrm{Xu}, \mathrm{D} ., \quad \&$ Shenkar, O. (2002). Note: Institutional distance and the multinational enterprise. Academy of Management Review, 27(4), 608-618.

$\mathrm{Yu}$, J., \& Cooper, H. (1983). A quantitative review of research design effects on response rates to questionnaires. Journal of Marketing Research, 20(1), 36-44.

Zhou, K. Z., Yim, C. K., \& Tse, D. K. (2005). The effects of strategic orientations on technology- and market-based breakthrough innovations. Journal of Marketing, 69(2), 42-60. 
Table 1: Demographic characteristics of the respondent firms $(n=246)$

\begin{tabular}{|ll|}
\hline Product Distribution & Percentage \\
\hline Communication Products & $12.1 \%$ \\
Systems & $6.3 \%$ \\
Computer Peripherals & $14.2 \%$ \\
Optoelectronics & $14.6 \%$ \\
Semiconductors & $15.8 \%$ \\
Computer Components & $37.1 \%$ \\
\hline Employee Numbers & \\
\hline Less than 100 & $20.0 \%$ \\
$100-199$ & $21.7 \%$ \\
$200-250$ & $26.7 \%$ \\
$251-999$ & $13.3 \%$ \\
$1000-4999$ & $14.6 \%$ \\
$5000-9999$ & $1.7 \%$ \\
10000 and above & $2.1 \%$ \\
\hline
\end{tabular}

\begin{tabular}{|ll|}
\hline Sales Revenue & \\
\hline NT100M-NT500M (US \$3M) & $19.6 \%$ \\
NT501-NT1B & $15.8 \%$ \\
NT1B-NT5B & $39.2 \%$ \\
NT5B-NT10B & $7.5 \%$ \\
More than NT10B (US \$300M) & $17.9 \%$ \\
\hline
\end{tabular}


Table 2: Measures ${ }^{\mathrm{a}}$ and composite reliabilities

\begin{tabular}{|c|c|c|}
\hline Constructs and measures & $\lambda$ & $\begin{array}{c}\text { Composite } \\
\text { reliability }\end{array}$ \\
\hline $\begin{array}{l}\text { Supplier's Customer Orientation } \\
\text { We can redeploy the strategic resources serving this international customer in the } \\
\text { global market faster than our competitors can. } \\
\text { We can realign our organizational processes with respect to this international } \\
\text { customer's changing needs ahead of the competition. } \\
\text { We can modify our products or services to accommodate this global account's } \\
\text { needs ahead of the competition. }\end{array}$ & $\begin{array}{l}.98 \\
.96\end{array}$ & .97 \\
\hline $\begin{array}{l}\text { Customer's Control } \\
\text { My company's production schedules are entirely determined by our international } \\
\text { customer's requirements. } \\
\text { My company's shop floor manufacturing processes are entirely determined by our } \\
\text { international customer's requirements. } \\
\text { My company's quality control procedures are entirely determined by our } \\
\text { international customer's requirements. } \\
\text { The selection of my company's supplier is entirely determined by our } \\
\text { international customer's requirements. } \\
\text { My company's storage and handling practices are entirely determined by our } \\
\text { international customer's requirements. }\end{array}$ & $\begin{array}{l}.81 \\
.67 \\
.72 \\
.69\end{array}$ & .86 \\
\hline $\begin{array}{l}\text { Technological Uncertainty } \\
\text { The technology in our industry is changing rapidly. } \\
\text { Technology changes provide big opportunities in our industry. } \\
\text { There are great technological innovations in our industry. } \\
\text { More complex products are provided in our industry. }\end{array}$ & $\begin{array}{l}.68 \\
.72 \\
.90 \\
.85\end{array}$ & .87 \\
\hline $\begin{array}{l}\text { Supplier's Innovativeness } \\
\text { In dealing with our most important international customer, } \\
\text { our firm's management actively seeks innovative ideas. } \\
\text { innovation is readily accepted in program/project management. } \\
\text { technical innovation is readily accepted in our firm. } \\
\end{array}$ & $\begin{array}{l}.87 \\
.91 \\
.69 \\
\end{array}$ & .87 \\
\hline $\begin{array}{l}\text { Customer's Dependence } \\
\text { Our international customer is strongly dependent on us. } \\
\text { It would be very difficult for our international customer to replace our production } \\
\text { or manufacturing. } \\
\text { It would be costly for our international customer to replace our production or } \\
\text { manufacturing. }\end{array}$ & .74 & .89 \\
\hline
\end{tabular}


Table 2: (continued)

Relationship Performance

Our relationship with this international customer has increased sales growth.

Our relationship with this international customer has increased market share.

Our relationship with this international customer has increased profitability.

Our relationship with this international customer has increased creation of new

products, product enhancements.

Our relationship with this international customer has enhanced product quality.

Our relationship with this international customer has gained more business

opportunities to cooperate with more international partners.

\section{CFA Model Goodness-of-Fit Indices:}

Chi-square: 436.31 on 237 d.f.

NNFI: .938

CFI: .947

RMSEA: .059

a All items were measured using a seven-point Likert scale ranging from $1=$ strongly disagree to $7=$ strongly agree 
Table 3: Intercorrelations and shared variances of measures $(n=246)$

\begin{tabular}{lcccccccc}
\hline & F1 & F2 & F3 & F4 & F5 & F6 & F7 & F8 \\
\hline Customer Orientation (F1) & .90 & .06 & .06 & .20 & .16 & .20 & .00 & .00 \\
Customer's Control (F2) & .25 & .54 & .02 & .08 & .13 & .09 & .02 & .00 \\
Technological Uncertainty (F3) & .24 & .15 & .63 & .04 & .02 & .07 & .00 & .01 \\
Supplier's Innovativeness (F4) & .45 & .28 & .21 & .69 & .14 & .19 & .00 & .01 \\
Customer's Dependence (F5) & .40 & .36 & .13 & .37 & .72 & .10 & .00 & .00 \\
Relationship Performance (F6) & .45 & .3 & .27 & .44 & .32 & .54 & .00 & .00 \\
Knowledge Distance (F7) & -.05 & .14 & .01 & -.05 & .02 & .06 & -- & .02 \\
Firm Size (F8) & -.06 & .0 & .09 & .10 & .00 & -.02 & .13 &.- \\
\hline
\end{tabular}

Note: The correlations are in the lower triangle of the matrix. Shared variances are in the upper triangle of the matrix. The average variance extracted is along the diagonal.

Table 4: Assessment of common method bias

\begin{tabular}{|c|c|c|c|}
\hline Model & $\chi^{2}$ & df & $\mathrm{p}$ CFI NNFI RMSEA \\
\hline M1: Null model & 4016.58 & 276 & $.000 \mathrm{n} / \mathrm{a} \quad \mathrm{n} / \mathrm{a} \quad \mathrm{n} / \mathrm{a}$ \\
\hline M2: Trait only model & 436.31 & 237 & $\begin{array}{llll}.000 & .947 & 938 & .059\end{array}$ \\
\hline M3: Method only model & 2484.14 & 252 & $.000 \quad 403.346 \quad 191$ \\
\hline M4: Trait and method model & 324.95 & 213 & $\begin{array}{llll}.000 & .970 .961 & .046\end{array}$ \\
\hline Model Comparison & $\Delta \chi^{2}$ & $\Delta \mathrm{df}$ & $\mathrm{p}$ Conclusion \\
\hline \multicolumn{4}{|l|}{$\begin{array}{l}\text { Testing for the presence of trait } \\
\text { factors }\end{array}$} \\
\hline M1-M2 & 3580.27 & 39 & $<.01 \quad \mathrm{M} 1>\mathrm{M} 2$ \\
\hline M3-M4 & 2159.19 & 39 & $<.01 \quad \mathrm{M} 3>\mathrm{M} 4$ \\
\hline \multicolumn{4}{|l|}{$\begin{array}{l}\text { Testing for the presence of a } \\
\text { method factor }\end{array}$} \\
\hline M1-M3 & 1532.44 & 24 & $<.01 \quad \mathrm{M} 1>\mathrm{M} 3$ \\
\hline M2-M4 & 111.36 & 24 & $>.01 \quad \mathrm{M} 2>\mathrm{M} 4$ \\
\hline
\end{tabular}


Figure 1: Conceptual framework

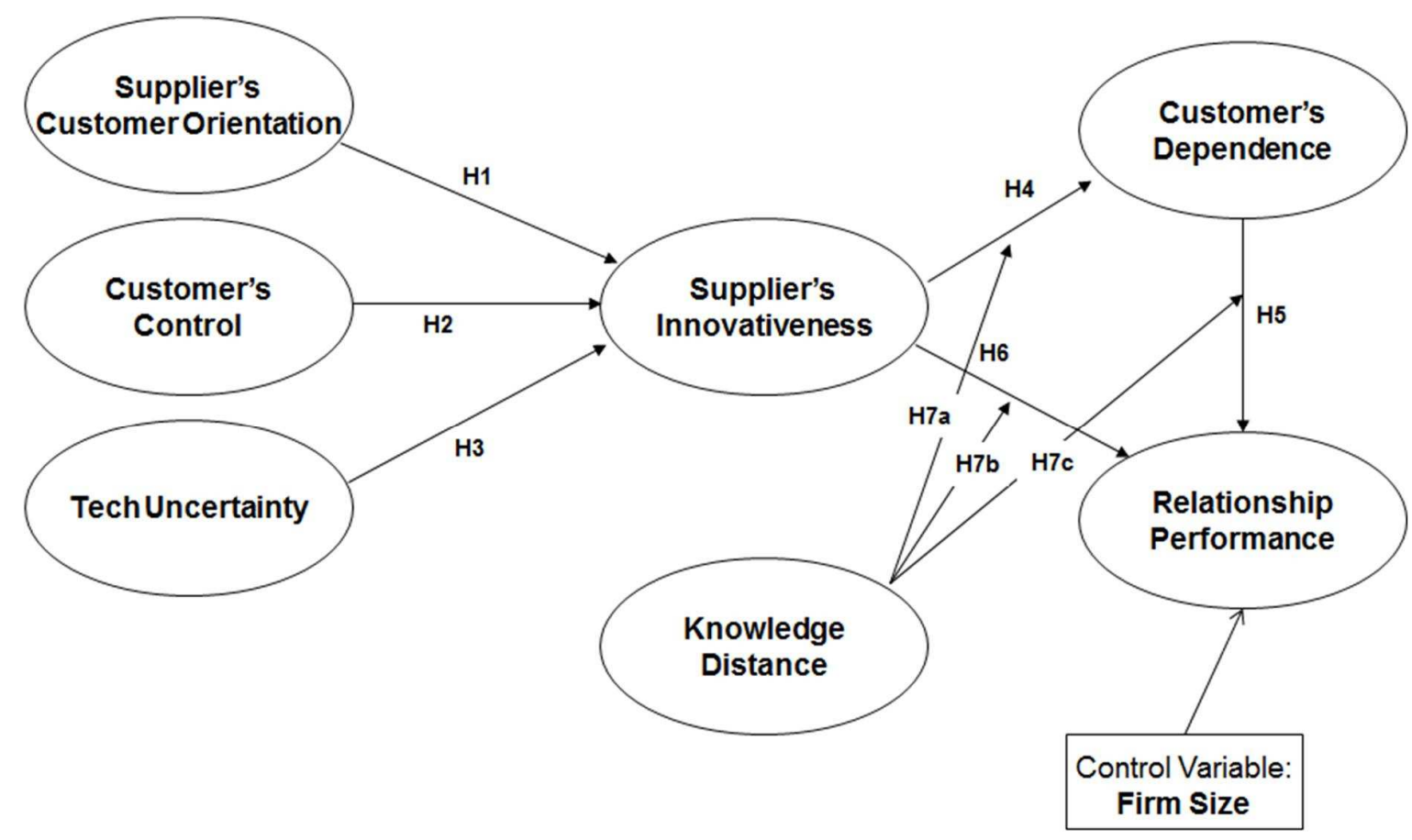


Figure 2: Results of final model estimation

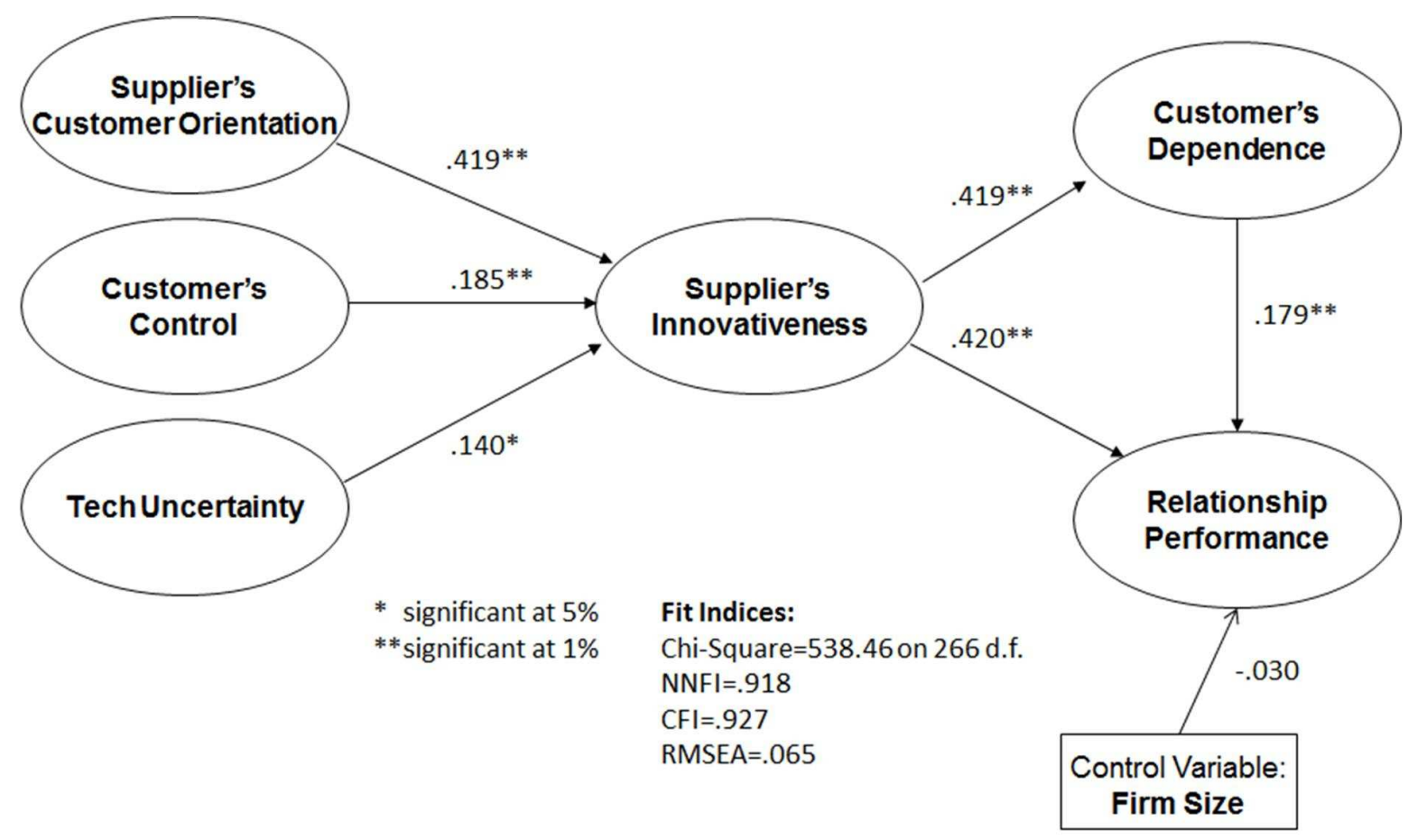


Figure 3: Moderating effects of knowledge distance

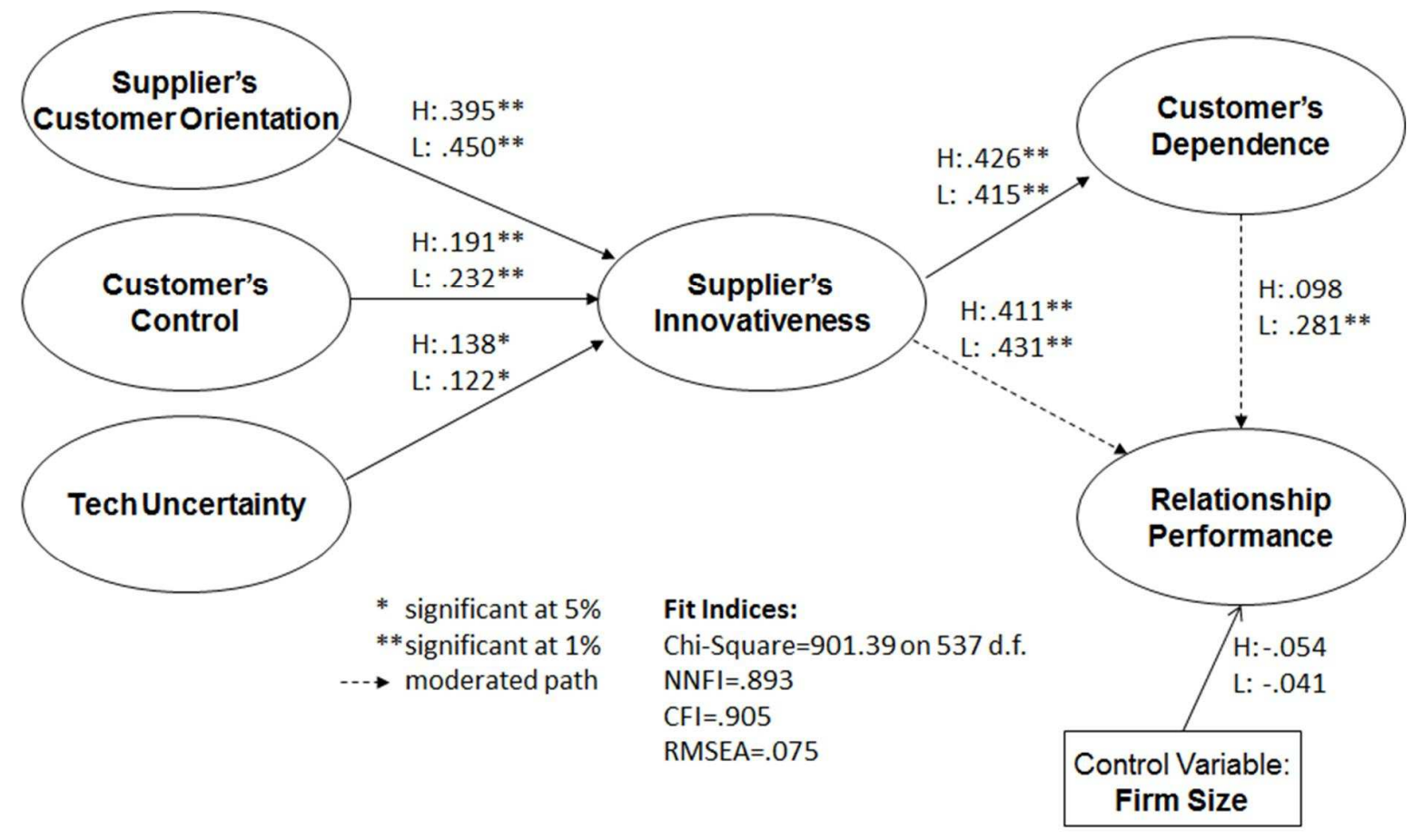

